\title{
The Uncertain Revival of Central Europe - Central European Thought from a Hungarian Perspective
}

\author{
ANDREA SCHMIDT
}

\section{sciendo}

Politics in Central Europe (ISSN: 1801-3422)

Vol. 16, No. 15

DOI: 10.2478/pce-2020-0001

\begin{abstract}
The recent crisis that, the European Union has had to face certainly raises questions about the current state of Europe. The question about the legacy of regional integration; the debate between the standpoints about the vision on the European Union with the necessity of strong nations or on the contrary, the opportunity of deepening the cohesion that could lead to the united states of europe; in other words, political integration, the deepest step of regional integration. the paper deals with the problem of the concept on central europe from the standpoint of various concepts; the question of mapping, the meaning of borders, the ways of identification appear in this paper. the difference between the concept of mittel europe and central europe also appear in the paper. analysing the question of central europe it is also inevitable to examine the meaning of central europe from historical context. after the end of the cold war and as the consequence of the euro-atlantic integration, the concept of central europe changed a bit. while during the bipolar system this phenomenon served as a differentiation of the groups of countries being located in the soviet sphere of interest. being central european meant something that was much more engaged with progressive approach in democratization, transformation rather than a sign of nostalgia towards the historical past.
\end{abstract}

Keywords: political map, regional integration, buffer zone, nation

1 This research project was supported by the European Union. EFOP-3.6.3-VEKOP-16-2017-00007 - Young researchers from talented students - Fostering scientific careers in higher education. 
"We have the chance to transfer Central Europe from a phenomenon that has so far been historical and spiritual into a political phenomenon. We have the chance to take a string of European countries that, until recently, were colonised by the Soviet Union, which would be founded on equal rights and transform them into a definite special body which would approach Western Europe not as a poor dissident or a helpless, searching amnestied prisoner but as someone who has something to offer." (Havel) ${ }^{2}$

The recent crisis that the European Union has had to face certainly raises questions about the current state of Europe. The question about the legacy of regional integration; the debate between the standpoints about the vision of Scruton's theory on the European Union with the necessity of strong nations ${ }^{3}$ which is shared by many of his conservative, or even radical followers, or on the contrary, the opportunity of deepening the cohesion that could lead to the United States of Europe ${ }^{4}$; in other words, political integration, the deepest step of regional integration.

Considering the perceptions about Central Europe, the region can be compared with a dying and rising deity (Majoros 2009) in such a perspective that, from time to time, the region remains in the focus of attention of the great powers while between two so-called active periods, the entire region is neglected. When acknowledging the existence of the internal cleavages within Europe it is worth examining the justification of this particular region. Our investigation focuses on the changing concept of Central Europe and the identification of this specific region, in addition to its rather questionable position being located between the East and West and finally, the attempts of bordering the region itself.

2 Havel, Vaclav: Allocution prononcée devant la Diéte et le Sénat polonais. Varsovie, le 25 janvier, 1990. In: L'angoisse de la Liberté. Paris, Éditions del'aube. 68-78 In: Denni, Karen (2009): Central Europe as a Transition Zone between East and West, Traditiones, 38/2 : 59-71

3 "Europe is, and in my view has ever been, a civilisation of nation states, founded on a specific kind of pre-political allegiance, which is the allegiance that puts territory and custom first and religion and dynasty second in the order of government." Available at: https://www.roger-scruton.com/articles/276the-need-for-nations (10 December 2019).

4 A famous Hungarian politician, Jászi Oszkár, composed his vision on the possibility of deeper inegration that could lead to the United States of Europe while, having experience about the consequences of the two World Wars, Winston Churchill also composed his idea regarding the strengthening of cooperation among the states of Europe. In: Bóka, Éva: Hungarian Thinkers in Search of Democratic European Identiy, Available at: http://www.grotius.hu/doc/pub/DJUNCB/eva_boka_hungarian_thinkers_eu_identity.pdf and Churchill, Winston: United States of Europe, Available at: https://winstonchurchill.org/resources/ speeches/1946-1963-elder-statesman/united-states-of-europe/ 


\section{Mapping the region}

'Europe' can be identified as a concept as well as a continent and the borders of both oscillate wildly (Jacobs 2012). ${ }^{5}$ A relatively recent and generally unaccepted theory sees Europe spanning half the globe, from Iceland to the Bering Strait, nearly touching Alaska. During the cold war, however, the opposite tendency triumphed more often: all of the Soviet Union, including Vilnius, Riga and other cities that today lie within the European Union, were excluded from Europe entirely. At times even the Soviet satellite states in the Warsaw Pact were left out, as well, so much had "Europe" come to be synonymous with "the West" and its associated political values 'Europe' became virtually synonymous with Christendom in the Middle Ages. In the past centuries, the unity was internationalised and less formalised or theorised. Religious ambitions or cultural projects united the Europeans because Europe was more a spiritual ideation (Maci 2011. According to Jacobs's interpretation, in the Middle Ages, 'Europe' became virtually synonymous with Christendom.

Borders are good examples of otherness that was constructed by separate trajectories and incompatible developments. ${ }^{6}$ Borders formulated the mental maps of Central Europe as they were functioning as the borders of the Empire of Charlemagne, which separated Christian Europe from the Slavs in the East and the borders drawn by the reformation and counter-reformation of the sixteenth century. Moreover, the borders between the Latin West and Orthodoxian East, or between Christendom and Islam, have to be considered. The old borders influenced the social, cultural and political life of the peoples living between them and were a marker of difference. The impact of these invisible borders can be seen even in our time and provides arguments for excluding those from Central Europe that are considered as Others, such as the Balkans (Denni 2009). Denni's argumentation corresponds with Sorin's remarks regarding the problem of a mental map of Europe. (Sorin 1996) Sorin argues that even for the generations after 1945, the mental map of Europe can be identified with the continuation of the perceptions about the more developed and backward parts of Europe. Since the age of enlightenment, there was a general perception that the progress of development obviously could approach from the West, however, until the Great Discoveries and the first roots of Capitalism, the South represented civilisation (see ancient Greece and the Roman Empire) while the North

5 Available at: https://opinionator.blogs.nytimes.com/2012/01/09/where-is-europe/ (10 December 2019).

6 It is very popular to deal with the division of Europe. The core and periphery theory by Wallerstein is based on the same ideology that was also described by the Hungarian historian Szücs Jenő in his work: Vázlat Európa három történeti régiójáról in the early 1980s. Szűcs Jenő (1981): Vázlat Európa három történeti régiójáról. In. Történelmi Szemle, 1981/3. Pp. 313-359 The importance of this essay - apart from the intention to write a synthesis comparing the different regions of Europe - was its delicate timing. The essay was published in the early 1980s and claimed that there was no homogeneous Eastern Europe. 
was identified with barbarism. From the 18th century, the symbolical existence of north and south made a turn and the contradiction between barbarism and civilisation could be drawn as an East-West axis. The Ottoman invasion and occupation of the Bohemian Kingdom, as well as the end of sovereignty for both Poland and Hungary, also deepened the East-West division.

Border as a phenomenon got its importance with the birth of the nation states in the $19^{\text {th }}$ century and kept it through several ages. After the First World War, with the collapse of the great empires in Central and Eastern Europe, state borders strengthened their separating role. Establishing borders was always a great challenge in the Central and Eastern European region. As for many decades, three great powers shared their influential zones over territories, it is rather difficult to speak about a common decision based on the interests of the local people. Decisions about borders are initiated for various reasons: borders can be created from above, by the state that naturally does not necessarily reflect the interests of the local population. Borders can be drawn from outside, too. Usually, that happens after the end of wars and in the majority of examples from past peace treaties, more often than not, only the winners have the chance to express their motivation. It is visible through several examples that such decisions seemed to serve only as temporary solutions and in many cases, they served as roots of further conflicts and lack of cooperation among negatively impacted partners. ${ }^{7}$ Borders can also be established from inside as a consequence of national claims; however, that is a rather risky solution from the ruling partner. Giving autonomous status or even supporting attempts towards independence can have dual consequences. In Central and Eastern Europe, ethnic and political borders did not coincide in the past two centuries and instead of homogeneous structures, multi-ethnic states were in the dominant position.

Border plays a rather socio-spatial role for the individual living close to it since it is/was part of daily spatial practice, while for someone living far from it, the border is/was more of a social construct of statehood. The visibility of historical borders sometimes reflects the electoral maps and demonstrates how historical territorial limits of a state become visible regardless of the fundamental escalating processes that have occurred in these states during the last 150 years (von Lowis 2015).

7 From the inter-war history of Poland, the conflict between Poland and Lithuania was a very good example of a lack of cooperation. The consequences of the Trianon treaty and the loss of the majority of its territory of Hungary after 1920, also determined the frames of the government's foreign policy. Everything was subordinated to the idea of territorial revision and that was the reason for mutual suspicion between Hungary and the neighboring successor states. 


\section{Central Europe versus Mittel Europa}

The terminology itself can refer to a 'middle' position and the region can be characterised from the historical or cultural perception as a "child of the West who later married the East" (Berend 2013). The region was characterised as the territory of German influence, or the frontier between the Catholic West and the Orthodox East, or in other words: the area where the East and the West meet. The name 'Central Europe' should be distinguished from the German name, Mitteleuropa, as the first name reflects a more geographical or cultural, historical entity, while the latter expresses more the importance of the region in the eyes of German ambitions towards this region; or, as Hanák mentions, one can speak about the resurrection of Central Europe and how it can be referred to as the absurd appearance of German imperialism" (Hanák 2018). However, the mapping of Central Europe can be a question of debate, even for scientists, artists and politicians living in this territory. It can be identified with the Habsburg Monarchy, accepting the fact that it is a constantly moving region, emphasising a lack of immutability (Romsics 2016). The mapping of the region is rather troublesome, as Central Europe can include and exclude the Czech lands, Austria and Germany; it can incorporate the Carpathian Mountains and can be a bridge to the Balkans or is understood as a sign of German imperialism.

The concept of Mitteleuropa is thus closely related to German nation-building and identity construction (Strath 2008). The concept of these uncertain frames of the European continent, however, goes back to the end of the Thirty-Year War, the roots of the Westphalian system. The balance of power in Europe was based on the expansion of sea powers like the British and French colonial empires, while the central part of Europe was characterised by the status quo of the German states, without a unified Germany and the presence of the empress belonging to land powers (Kiss 2010). The Holy Roman Empire ended in 1806 and the various political groups could not agree on what had to be included in a new second Reich. This conflict affected relations between Austrian and Prussia, or the Habsburg and the Hohelnzollern, or the Kleindeutsche and Grossdeutsche proposals of what should be in and what should be out. German visions got an additional impulse by the liberal economist, Friedrich List, with the idea of a mitteleuropaische Wirtschaftszone and Karl Ludwig Freiherr von Bruck, the Austrian politician, with the idea of the German Zollverein. Both concepts were focusing on the question of how to modernise the region and how to shape them into becoming equal competitors of the West. List emphasised his standpoint that, "a strong nation required a strong economy and vice versa. The nation-state's task was to protect the economy and through the economy, the national interest" (Strath 2008). His idea was extended with the suggestion that external protectionism and internal free trade, through a customs union, among the German states, were seen as crucial instruments in promoting the 
idea of a German nation-state, including Austria. In his later draft, as Strath remarks, he extended the proposed customs union to include Central Europe. He advocated the whole of Central Europe as a free trade zone that should be established as the first steps towards eventual political cooperation.

The Spring of Nations, the revolutions in 1848, added a new layer to the concept of economic cooperation. The discourse was extended with new ideas such as democracy, socialism, nationalism finally mixed up in the one discourse of liberty and progress. In the new vision of Mitteleuropa, led by a unified Germany, Austria's Germans would provide a bridge between the German core territories and the South-East European peoples. The year of 1849 became a turning point in the future of the Central European nations. After the unsuccessful end of the Spring of Nations, in the groups of disenfranchised and stateless groups of immigrants, a new idealistic utopia of the Danube confederation was being planned simultaneously with the idea of the federalist transformation of Central Europe, initiated by Adam Czartoryski in exile (Trencsényi 2016).

While the German Mitteleurope concept in the mid-1800s was more identified in pure geopolitical, economic and military terms, Bismarck's vision two decades later focused on the new European balance of power focusing on Mitteleuropa from the scope of Prussia. He described a Mitteleuropa based on the reconciliation between Prussia and Austria and having it stretch from the North Sea and the Baltic to the Adriatic and Black Sea under German hegemony. With his dismissal, his limited ambitions on a limited Central Europe changed into a colonial and imperial vision of Mitteleuropa based on economic cooperation but already with German dominance. A strong Mitteleuropa under German hegemony, as Strach mentions, was perceived as a precondition for overseas colonial expansion. Although German overseas expansion created tensions with France and Britain, the continental expansion created tensions with Russia.

The idea of Middle Europe was also strongly connected with the post-Napoleonic French initiatives regarding control over the narrow belt between imperial Russia (later the Soviet Union) and the increasing unified German state referring to the 'Eastern Question', the declining Habsburg Monarchy and the more and more determining national question. The concept itself was however supported by the Austrian government, too. Metternich was the first Austrian politician who used the word Mitteleuropa. This construction focused on the role of the Habsburg Empire and described a more geographical than political unity.

The so-called Mitteleuropa concept received an extra impulse in the first years of the First World War when Friedrich Naumann composed his vision and the role of German participation in this construction. The German-led Mitteleuropa concept was popular until the Axis powers were in a winning position. Their defeat and the collapse of the Habsburg Monarchy into successor nation states, however, redefined this concept. The Mitteleuropa vision counted on economic 
integration between Austria and Germany that naturally put Hungary into a subordinated position. Although Naumann emphasised a more economic cooperation that could surely lead to a stronger political cooperation, the Hungarian government of the Austro-Hungarian Monarchy was as pessimistic in 1918 regarding the Hungarian (and Austrian) position in such a construction as the Hungarian media. ${ }^{8}$

\section{Table 1: Dimensions of Mitteleuropa}

\begin{tabular}{|c|c|c|}
\hline & Dimension & Forms of integration \\
\hline \multirow{2}{*}{1.} & \multirow{2}{*}{ Economic } & List: Zollverein \\
\hline & & Naumann: Mitteleuropa's Plan \\
\hline 2. & Political & $\begin{array}{c}\text { Common interest, empire building strategy: } \\
\text { against France in the West, against Russia in } \\
\text { the East }\end{array}$ \\
\hline 3. & Geopolitical & $\begin{array}{l}\text { Germany's 'middle' position, double edges, } \\
\text { Ostpolitik, or neighbourhood policy }\end{array}$ \\
\hline
\end{tabular}

Source: author

After losing the war and the collapse of the Habsburg Monarchy, these German claims obviously had to be reduced and the structure of the new independent small states got a new name, Zwischeneuropa (Miletics - Pál 1998). This concept was the extension of Haushofer's theory regarding Mitteleuropa. He described this region, the chain of the states of the Little Entente, as the buffer zone created by France, emphasising the French claims towards control over this region. With the collapse of the two empires, these successor nation states composed a power vacuum being located between two dubious great powers Germany was far weaker than before entering the war, while the Eastern neighbour had to struggle with the construction works of a new empire, called the Soviet Union. The new successor states also found themselves in an ambiguous position (Hamerli 2018). The Hungarian views from the interwar period, however, emphasised more the federalist views with the exclusion of the Germans and

8 Available at: https://www.eleveltar.hu/kereso-portlet/displayimagepopup?type=file \& id=fOdaabb3a714-4f08-bb4f-58b48b4a6904 (10 December 2019) and Lengyel, Géza: Mitteleuropa, In: Nyugat, 1916. 8. 
neglecting German efforts. According to the Hungarian vision, the Danube basin served as the core of the reorganisation of a fragmented Central Europe. Several concepts crystallised, from the federative concept to the revisionist solution. Oszkár Jászi, already in exile, expressed the necessity of peaceful federative cooperation between the new small successor states, while József Csetényi underlined the importance of revisionism as a natural and necessary consequence of the decision that disintegrated the Habsburg Monarchy. ${ }^{9}$

\section{Table 2: Definition of Central Europe}

\begin{tabular}{|c|c|}
\hline $\begin{array}{c}\text { Topographical position } \\
\text { Physical }\end{array}$ & Hard to find the frames, frequently changeable \\
\hline Historical or political concept & $\begin{array}{r}\text { A region that is based on one or more criteria or } \\
\text { doubts } \\
\text { Germany Plus, Ostsiedlung }\end{array}$ \\
\hline Geographical region & $\begin{array}{r}\text { Equipped with physical and human elements } \\
\hline\end{array}$ \\
\hline
\end{tabular}

Source: author

Discourse on Central Europe usually focused on various elements, for example, the geopolitical perspective Central Europe served as a buffer zone between great powers which was characterised by the presence of small states, instead of great power status in the interwar period. This status limited the opportunity to get involved with the experience of independent states as this region served several times as a playground for the two neighbouring great powers: Germany and the Soviet Union. The Second World War resulted in the reshaping of the states of the European continent and so the integration process became more emphasised. In Western Europe, as a sign of losing the colonies, the process of integration became appreciated, while in the East, the influence of the Communist Soviet Union almost entirely covered the instable group of independent successor states from the interwar period (Snyder 2019).

9 We want to recreate such a Hungary that is not any more a toy of any great power, that can declare about its aims by itself; a Hungarian state that has great importance in the reorganisation of the Danube valley, a concept which is acclaimed by the world and to which the aims of Transylvania, Croatia and Upper Hungary (the territory of Slovakia) can also be included, first of all because their aims are similar. Available at: http://mtdaportal.extra.hu/books/csetenyi_jozsef_revizio.pdf (10 December 2019). 
Central Europe is usually defined as a zone or 'cleavage' between the East and the West, or it can also be understood as a conflict zone that was affected by two tendencies in its historical past; the idea of unity that implies a homogeneous region and resistance to these efforts and the struggle for autonomy of the people living in Central Europe (Denni 2009). Thus, it appears its in-between position gives the opportunity to adopt Western values while keeping Eastern traditions at the same time. One can doubt if this position is treated as an advantage or as a position that hampers orientation towards the West.

This Central European region can also be identified as a melting pot of several ethnic groups and religions which lived among peaceful conditions, despite the fact that, from time to time, different attacks reached the region from different directions. The $19^{\text {th }}$ Century, however, stopped the peaceful coexistence of different groups as nationalistic ambitions determined the future of the local population. The late 19th Century was the era of the linguistic nationalism that was widespread in the three historical states; in the Polish, Czech and Hungarian communities. Each nation was in a discrepant position not having independency and being part of multi-ethnic empires (Bibó 1986). According to Bibó, the roots of nation states appeared much earlier than the first steps of the modern state. One of these features is the use of language, or at least its own dialect. Monolingualism, as Bibó remarks, was a natural consequence of the political, cultural or religious hegemony of the predominance of stronger monarchies. Obviously, several European language borders preserve the memory of the late political borders. ${ }^{10}$

The First World War made this situation even more complicated as in these confusing times, different nations wanted to reach a new step in their demands: an independent nation state. The reign of linguistic nationalism finally led to the plasticity of the borders in the Central European region. In Western and Northern European cases, historical status quo assisted in the maintaining of the importance in nation building and the old borders in Central Europe either became lost (in the Balkans) or weakened and led to the desperate disputes about new borders. The final decisions were finally made violently by great powers, however, until the final decision/fatal events happened everywhere. Speaking about another critical zone, Appelbaum remarks that these national demands could develop into armed conflicts quite easily (Appelbaum 2016).

\section{Central Europe - an experiment}

Central Europe can also be explained as an experimental region of the ambiguous approach towards modernity. One of the most visible differences between

10 Bibó, István: Az europai egyensúlyról es a békéről, In: Bibó, István: Válogatott tanulmányok 1935-1944 I/ pp. 318-319 
the Eastern and Western European approach can be observed in the direction of social integration. This division can also be explained as a consequence of the belated embourgeoisement (Hanák 2018). Hanák points out that this missing social class was replaced by the nobility instead of the French traditions sodden by the principles of the Enlightenment; romantic German visions became well accepted. That corresponds with Rupnik's statement, who emphasises that the nations of Central Europe "were built on the ruins of multi-national empires (Habsburg, Ottoman, Russian); they began as nation-states that were nothing of the kind".

Hanák calls it the position of a ferry adopting the phenomenon from the famous Hungarian poet and representative of the Hungarian political journalist, Endre Ady. Returning back from Paris and getting influenced by Western political ideology, Ady, in his work, compared Hungary to the ferry that was lurching between the two banks of the river and which was not able to calm down. The metaphor about Hungary as the ferryboat between the East and West, however, became a determining element of Hungarian political culture. ${ }^{11}$ It can refer to instability towards modernism that can develop into a general social crisis in Central Europe. ${ }^{12}$

The region, that is not defined entirely, can also be referred to as an experiment that belongs to an imagined reality. T.G. Ash also argues that, unlike North America, Central Europe is not a geographical unit but rather a spiritual or mental entity. Central Europe exists in an imagined construction, a mental approach in order to distinguish people from this region from the Orthodoxian, less developed, Eastern neighbour. It connotes perspectives with a desire to construct, to approach something. It can be a cultural community or a pure desire for economic cooperation that can lead to economic, or in the future, political integration.

Central Europe as an uncertain entity has got different descriptions. One of the bizarre names was the "invisible snail shell." ${ }^{13}$ With this remark, Szilágyi-Gál emphasises the experience that, since 1989, through the process of European integration, the opening of the borders, the free movement of the population, as well as the free flow of information, old experiences and perception

11 „Kompország, Kompország, Kompország: legképességesebb álmaiban is csak mászkált két part között: Kelettől Nyugatig, de szívesebben vissza." (Ady) The metaphor of "ferry country" (found in the first part of 'Ismeretlen Korvin-kódex margójára') not only presents a choice between the 'barbarian' East and the 'civilised' West, Asia or Europe, it is also a rewriting of the East/West opposition (a central topic of the area's intellectual history) and the Hungarian national character from a more provocative and tragic standpoint. http://hungarologia.net/wp-content/uploads/Teslar-Akos-rezume-hu.pdf

12 However, this approach was extended with a new narrative from the Hungarian politicans. Being the part of Central Europe Hungary was mentioned as a defence and civilisation metaphor in Hungarian and European public discourse (Glied - Pap 2016).

13 Szilágyi-Gál, Mihály: A fal közöttünk In: Közép Európa, felejtsük el? Available at: http://ketezer. hu/2015/02/kozep-europa-felejtsuk-el-3/ (10 December 2019). 
remained recognisable, in particular, in the case of cultural and livelihood obstacles, namely the financial gap between the East and West. There are other perceptions that focused on the question of Central Europe as a "sign of revolt against the decision of great powers, the revolt against the Yalta system". However, this revolt was focusing simulatenously on the relationship with the West and the special ties with history. ${ }^{14}$ The relation to Central Europe can be different from the point of view of the investigators. The Serbian standpoint, for instance, was rather controversial towards the division of Europe and the territorial frames of Yugoslavia. From the Serbian point of view, Central Europe was identified with regional imperialism conducted by Croatia and Slovenia. ${ }^{15}$ The idea for Central Europe from the Serbian perspective was usually a debate on inclusion and exclusion. It was also pervaded with the idea of superiority in civilisation and attempts for internal colonialisation. That process was in accordance with the metaphor of the Balkans that, in the historical past and in most recent years, it was equivalent with backwardness. As the Balkans meant something underdeveloped, of second-class quality, nobody wanted to belong to them. Eastern Europe was also such a phrase that was better to avoid mentioning. The definition of Central Europe was also uncertain as the phrase Eastern Europe also had some kind of negative connotation. That corresponds with Romsics's argumentation that quotes the Hungarian ambassador in the 1930s in Berlin, Döme Sztójay, who became the Hungarian Prime Minister in 1944. Participating in a meeting with German partners, he exclaimed, arguing that identifying Hungary with the Balkans could be defined as hurtful to Hungary. ${ }^{16}$ Maybe that was the reason why the US administration ordered, in the 1990s, in the case of those states that were already in negotiation of the Euro-Atlantic integration, to be referred to as Central Europe in order not to hurt them by defining them as parts of Eastern Europe.

Common cultural values such as the appearance of different styles in architecture and in the arts also serve as reference points. Hanák found the Baroque style as an organising power and a connecting element that was present in music, opera, ballet, palaces and the comprehensive modern urban landscape from Munich to Salzburg and from Prague to the smallest Hungarian villages.

14 Horváth, Sándor: Kell nekünk Közép-Európa (is) Available at: http://ketezer.hu/2015/02/kozep-europa-felejtsuk-el-3/ (10 December 2019).

15 Losoncz, Alpár: Velük elkezdődhetne In: Közép-Európa - felejtsük el? Available at: http://ketezer. hu/2015/02/kozep-europa-felejtsuk-el-5/ (10 December 2019).

16 Ne beszéljenek Magyarországról mindig úgy, mintha az a délkelet-európai térséghez vagy Délkelet-Európához tartozna. Magyarország nem számítja magát a Balkán-népekhez, és sértésnek érzi, hogy mindig egy kalap alá számítják. (Don't speak about Hungary as being part of the Southeastern region, or South-eastern Europe. Hungary does not treat itself as part of the Balkan region and takes it as hurtful being evaluated as equal to them.) In: Romsics, Ignác: Közép- és/vagy Kelet-Európa - egy definiciós vita és ami mögötte van, In: Korunk História, 2016/7 Available at: http://epa.oszk.hu/00400/00458/00549/ pdf/EPA00458_korunk_2016_07_074-089.pdf (10 December 2019). 
This Central European universalism got its first push in the early 19th Century with the influence of nationalism. Although the Habsburg Monarchy could be defined as an outstanding example of multiculturalism, the heterogeneity of different languages and religions, with the German language as the main element of cohesion and the influence of the Jewish population as one of the most 'cosmopolitan' groups. The strolling players, musicians and painters and the Jewish population were more mobile in contrast with the rural population before the capitalist era. While on one hand, the cultural and territorial self-awareness became the ruling ideology, in the royal court, ever newer plans started to focus on the accentuation of the plurality of the region (Hanák 2018).

A similar standpoint appears with Czesław Miłosz. For the Lithuanian-born Pole, Central Europe encompassed a whole swathe of territory that ran from 'Baroque Vilnius' in the north to 'medieval Renaissance Dubrovnik' in the south, encompassing pretty much everything that lay to the east of Germany but which was predominantly Catholic and Jewish in heritage. ${ }^{17}$ The most spectacular elements of this heritage can be observed through loanwords and the family names which demonstrate a long-lasting community from the historical past.

Multiculturalism and multi-ethnicity were interrupted by the decisions of the new territorial structure of the region. Paradoxically, despite the almost one-hundred-year distance since the collapse of the great empires and the birth of the successor states, these signs of multicultural structure and heterogeneity are still visible, in particular, at the two parts of the state borders. The Habsburg Monarchy itself was a total contradiction of values. On one hand, there existed an old-fashioned bureaucratic, centralised governance which stood on one side and a more liberal, economic policy with a freedom for the flow of ideas, persons and goods on the other, together with an idealistic common currency, a lack of censorship and the natural multilingual atmosphere among the urban population. In his essay, The Deformation of Political Culture in Central and Eastern Europe, Bibó remarks, "as a result, the ending of the social role of a unified European aristocracy elicited a much greater shock in Central and Eastern Europe than in the West, where a developed social structure no longer or less typically based on birth privileges was by that time ready to take over the aristocracy's role... All the threads point towards some kind of political hysteria and in dismissing political hysterics, the first task is to disclose the historical shocks disturbing the development and balance of these countries. We should be suspicious of two things: the premature, explosion-like character of their democracy and the resulting difficulties in the formation of national frameworks" (Bibó 1986). As he further remarks," the ultimate tipping of the inner political balance was, however, due to the painful and difficult process of nation formation." He further added that "the nations living here lacked

17 Available at: https://www.eurozine.com/growing-up-in-kunderas-central-europe/ (10 December 2019). 
what the Western European nations possessed in a self-evident and tangible way, both in reality and in the communal consciousness: the actual existence of their own state and national framework, a capital, the harmonious functioning of politics and economy, a unified social elite, etc." A lack of democratic values and the uncertainty of their material status also led to an instability of political culture and a controversial approach towards democracy. As Bibó underlines, the approach to democracy was also a weak point in this region. Democracy was a gift that was probably spread too early as social transformation was still in a more backward, unstable position. Adapting democratic values was not the result of internal social development and as it was recognisable in various parts of Central Europe, nationalism won over democracy. Bibó linked together the acceptance of democratic values and the fear of uncertainty. The lack of stability, the reality of the frames of own nationality, the missing state, capital city, well-functioning economic and social communities, steady elite - these factors all assisted in the raising of the Western countries.

The 19th Century and the idea of nation states determined and predetermined the ethnic conflicts in the future. It was the general aim of the nationalist parties and philosophers to accept the 'one culture - one nation - one state' theory, which was later modified in practice with the reconstruction of the new borders and nation states of Central Europe after the First World War. The new successor states assisted in destroying Central Europe by the dissolution of the Habsburg Monarchy in 1918 that - according to Hanák - was still by far the most stable construction in the region. In 1918, all dynastic constructions collapsed in Central Europe and the partition of the Habsburg Monarchy was the most convenient scenario. The idea of emphasising the language borders and the possibility of self-determination was an adequate solution. The catastrophe and the roots of further conflicts, as Bibó remarks, are based on the inadequate implementation of the ideas by refusing ethnic unifications and neglecting historical claims towards given territories. On the other hand, geographical, economic, strategic and infrastructural claims were taken into account that sometimes overwrote the natural claims of the local population; the newly created borders sometimes managed to recall further debates, in particular if a given ethnic group became cut off from the historical hinterland by becoming part of such a state or community with which they had no or limited connection in the historical past, or any cultural ties. These debates are sometimes influenced by the fear and uncertainty of their citizens and the statistical data on ethnic composition served several times as a reference point in order to strengthen their claims. ${ }^{18}$

18 The entire Hungarian foreign policy was determined by irredentism. The German assistance in territorial claims was a good excuse of the support of the Nazi Germany. Within the territorial extension with the German and Italian diplomacy in the late 1930s early 1940s Hungary managed to get back the majority 


\section{The Rebirth of the Central European Concept}

The Central European vision remained an idea after 1945. It was in a dead stage until the 1980s. As the whole Central and Eastern European region belonged to the sphere of interest of the Soviet Union, it was hardly possible to discuss any kind of cultural, ethnic or even religious gaps. The deepening process of integration in the West and the birth of the opposition movements in the Soviet Bloc assisted in the popularity of ideas about integration. The years between 1984 and 1989 were the peak of discourses on Central Europe. There was a common agreement that Central Europe coincides in the content of the works dealing with the region, namely that the society of Central Europe is closer to the West in culture but closer to the East in political culture and system and obviously, they are also different from the Russians. This new wave of debate was based basically on two texts: Milan Kundera's "The Tragedy of Central Europe", from 1983, and Konrád György's text "The Dream of Central Europe", published in 1984. ${ }^{19}$ There existed, however, a third one. Jenő Szűcs, a Hungarian historian, breaking with the previous, more Soviet-friendly or Marxist ideology-friendly Hungarian standpoint, introduced a triple-divided concept with Central Europe as a hybrid region (Romsics 2016). Analysing Central Europe as a separate entity questioned the legacy of the bipolar division of Europe.$^{20}$ Szücs developed an extended model to reflect internal cleavages within the European continent, arguing that the gap between the more developed West and the (eastern) periphery could be explained by several historical and economic factors (Schmidt 2016). The novelty of Szúcs's theory, based on the fact that he distinguished a separate region between East and West while discrediting the previously existing Western standpoints regarding how everything lays beyond Leitha, or Austria, is identical with the East but it was also a critical argument against the Soviet Union with the statement that there is a separate 'middle' region. Working in Budapest and writing in Hungarian, Szücs's theory never achieved such a great influence in the Western world as Konrád's or Kundera's works, as they both published their essays abroad, but his essay did provoke a general debate in Hungary in the 1980s. What Konrád emphasised in his later published works

of those lands that were within the ethnic, language borders however at the end of the Second World War there was no supporter of the Hungarian claims.

19 The orifinal version was read by Konrád as an essay that was his acceptance speech he told in 1984 after receiving Herder prise at the ceremony in Vienna in the Schwarzenberg Palace.

20 In the 1960s and 1970s, Halecki's division of Europe he worked out in exile was accepted with much controversy among Hungarian historians. Speaking or writing about triple division with a separate Central European region that was distinct from the Soviet Union expressed a denial of a homogeneous Socialist bloc. The acceptance of this structure was ambiguous, even from the US audience. In Hungary, it was treated as a harmful influence of the Western emigrant (and definitely suspicious), or at least a subversive view. 
on Central Europe was the importance of the Central part as "the way from West to East leads via Central Europe.

As Kaczorowski remarks (Kaczorowski 2017), Kundera managed to ensure at the same time several independent Central European circles, both in exile and in their home country. The reasons and the influence of these debates led to various consequences. Central Europe as a phenomenon was also functioning as a tool for the opposition groups of the socialist bloc states to separate themselves from the values of the Soviet Union by demonstrating the otherness and the acceptance of Western principles, as was recognisable in the early 1990s. Among the consequences of the revolutions of Europe in 1989 was a profound reordering of the spatial imaginary of Europe. The collapse of both the Berlin Wall and the Soviet bloc called for the creation of new geographical stories and new spatial representation that could capture and codify the cartographic chaos of the former Eastern European space (Bialasiewicz 2003). As Ash points out, in the first half of the twentieth century, the debate about who did or did not belong to Central Europe had real political significance, much like it does today. Being 'Central European' in contemporary political usage means to be civilised, democratic, cooperative - and therefore to have a better chance of joining NATO and the EU. In fact, the argument threatens to become circular: NATO and the EU welcome 'Central Europeans' so 'Central Europeans' are those welcomed by NATO and the EU.

Central Europe was a historical and geopolitical challenge whether these sates were capable of being ready to establish their regional cooperation models such as the Visegrad group or the Central European Initiative (previously Pentagonale and with the inclusion of Poland in 1991, the Hexagonale), pointing to the practice that, from the late 1980s early 1990s, Central Europe was also understood as a geopolitical concept determined for cooperation with neighbouring countries representing a political and economic vacuum by not belonging to the Soviet bloc anymore and still waiting for an invitation to the European Community. This unrepeatable moment was a challenge for the region; they had to make a great effort to break up with deep-seated norms and habits and focus on peaceful and effective cooperation. Although the followers of the idea of regional integration were satisfied with any attempt of contribution among the post-Soviet bloc member states, each type of contribution could stagnate at a certain point. The Visegrad Group could serve as good practice for Central Europe, however, as he remarks, it is a challenging issue on how to find common interests between a Poland that is preparing for the position of the 'regional leader', while for Hungary, the frames of orientation are still the no longer existing boundaries of the Carpathian basin and it is still fighting for its position from a separated perspective, while Austria transformed into a 'German suburb. The position of the Central European region is rather ambiguous regarding the question of common interest. Regarding the pieces of 
the great Central European as an entity instead of a convergence, a moderate but intensifying disintegration and uncertainty is visible. As is proven from time to time, post-Communist countries competing with each other are moving apart from the desired and emphasised Western values, demonstrating a kind of common relation with the values engaged with the South European region. Poland, as Neumann also remarks, is building a "Nordic secondary power", while "almost Austrian" Slovenia, the "best pupil" from this polychrome class, is in crisis, Hungary is fighting for its position against the West and opening its doors to the East; Germany and Austria are not really willing to share a common interest with this region and Russia from the East is getting more and more involved with it. ${ }^{21}$

As in the 1990s, Central Europe could be understood as a sign of demonstration; nowadays, it can be called more like a 'lab for paradigm', where such processes took part in the past that got global importance for the present - among others, the treatment of differences, otherness and strangeness. ${ }^{22}$

The collapse of the Berlin Wall and the end of the Cold War revoke the old discussion about the symbolic geography of the Central European region. The reality of the Iron Curtain legitimised the East-West division of Europe by creating a political, cultural and even civilisation cleavage structure of the continent by creating two blocks: the more developed Western and the Soviet-orientated Eastern bloc. The questionable point was the location of the divided two Germanys which, according to the classical, historical division, for several centuries was considered part of Mitteleuropa, while within this division and under the influence of Western powers, West Germany underwent a rapid Westernisation while the East German state remained a stable part of the Soviet Bloc, together with the remaining Central European states - except Austria (Majoros 2009). This concept survived the two World Wars and the main ideologist of this ideology was Kundera and his famous work, "The Tragedy of Central Europe". ${ }^{23}$ "As a result, three fundamental situations developed in Europe after the war: that of Western Europe, that of Eastern Europe and, most complicated of all, that of the part of Europe situated geographically in the centre-culturally in the West. ${ }^{24}$

21 Neumann, Ivor: Available at: http://ketezer.hu/2015/02/kozep-europa-felejtsuk-el-3/ (10 December 2019).

22 Csaky: Op.cit.

23 In fact, what does Europe mean to a Hungarian, a Czech, a Pole? For a thousand years, their nations have belonged to the part of Europe rooted in Roman Christianity. They have participated in every period of its history. For them, the word "Europe" does not represent a phenomenon of geography but a spiritual notion synonymous with the word "West." The moment Hungary is no longer European - that is, no longer Western - it is driven from its own destiny, beyond its own history: it loses the essence of its identity. "Geographic Europe" (extending from the Atlantic to the Ural Mountains) was always divided into two halves which evolved separately: one tied to ancient Rome and the Catholic Church, the other anchored in Byzantium and the Orthodox Church.

24 Kundera: The Tragedy of Central Europe Available at: http://www.kx.hu/kepek/ises/anyagok/Kundera_tragedy_of_Central_Europe.pdf (10 December 2019). 
Not only did it argue that Central Europe constituted a "kidnapped West" abducted by an alien, Byzantine-Bolshevik civilisation but it also claimed that the rest of the continent was in too deep a state of decadence to be fully aware of what it had lost. Kundera believed that Central European nations had reportedly tried to join Europe; they even managed to harbour vestiges of European culture under the oppression of Soviets while in the West, so Europe changed dramatically. As she points out, when dissidents and émigrés entered the West, they were already disappointed that the "Europe itself... was no longer experienced as a value." 25

That remark corresponds with Lengyel's opinion arguing that this general crisis of European values is embedded in the consequences of the two world wars. Facing the historical past immediately requires the problems of the actions the given states did or did not do in the past centuries or decades while it is one of the values in accordance with the problem of sovereignty. The predominance of historical past, the reference points chosen by, in particular, the populist or nationalist politicians can even hamper necessary cooperation (Lengyel 2016). While Kundera believes in Central Europe, the heir of the Austro-Hungarian Empire, that is a territory of small nations pained by a profound feeling of uncertainty over their existence, they may disappear any time just like Poland and Czechoslovakia did repeatedly, or their borders and population may vary - as was the case of Hungary. ${ }^{26}$ This argument corresponds with the phenomenon because of what Hungarian politicians and historians are reportedly criticised for. The reference point for Hungarians regarding the perspectives of Central Europe in the future is still a nostalgia towards the Habsburg Monarchy and with the borders of historical Hungary. The misunderstanding of the problems of the Central European region from the Western perspective can be explained because of a lack of information about the geopolitical and historical facts of this region and because of the fact that the subordinated position of this region did not give the possibility of distinct states to be more or less adaptive towards the policy of the Soviet Union. The entire region was subjugated by Moscow and the only difference was the ability of integrating them according to the principles of Eastness.

\section{The raison d'etre of Central Europe}

Thirty years on, most of the countries in Kundera's Central Europe have been integrated into the European Union and NATO and the very term "Central Europe" is no longer necessary, neither as an anti-Soviet rallying cry nor

25 Kepplová, Zuzana: Could the Real Tragedy of Central Europe Please Stand up? Available at: https:// visegradinsight.eu/recycled-rhetoric/ (10 December 2019).

26 Keppova, Op.cit. 
a badge of cultural belonging. However, the cultural concerns addressed by Kundera have not necessarily gone away simply because the context has changed. Europe is still sandwiched between two superpowers with differing worldviews, and small nations can still be the bearers of important truths. ${ }^{27}$

In the 1990s, two tendencies developed: the slower than expected wave of integration and the renaissance of the nation states. The latter was common, in particular in the Eastern region. As a result of transition, the post-socialist world experienced the rebirth of nation-states on the map of Europe on one side and the collapse of the Soviet Union, Czechoslovakia and Yugoslavia on the other. The project carried out in Europe by what we call the European Union, with its centre located in Brussels, gives an identity with which we can find ourselves - an identity we can assume (Maci 2011)? The problems of the East-West dimension could be embraced in the discussion about EU membership, or EU scepticism. In the shadow of the referendum on Brexit, Scruton's critical argument regarding the dilemma between stronger nation states or deeper integration is still a current issue. As he says, the EU tries to demolish the territorial legal authorities such as national faith, all the elements that have been the bases of European legitimacy since the era of enlightenment (Scruton 2005).

EU membership can thus be characterised as a final proof that the transformation is over; however, it resulted in new problems that ask for solutions. Among others, the following issues can be mentioned: dangerous nationalism, xenophobia, 'delocalisation', the problem of immigration and competition for cheap labour, 'social dumping', etc. (Schmidt 2010).

Looking at the position of Central Europe in the 20th century, these changing waves of the influence of the great powers can be recognised from the years of the First World War. During the war, the region was standing in the focus of Germany, while in the interwar period, Germany was replaced by France, whereas from the 1930s, German interest also intensified. The years between 1945 and 1947 can be characterised as an uncertain attempt from the great powers towards the region but this action was interrupted by the Soviet Union based on the decision accepted in Yalta and Potsdam. Right before the transformation, the French enquiry intensified in accordance with increasing German attempts. These countries are, economically and politically, the most closely tied to Germany, which was the main driver for their integration into the EU.

According to his standpoint, interest towards the Central European region becomes more visible in cases where any ambitious state from the region attempts to take on the role of actor responsible for the region, whereas if any great power tries to rule the region, it usually manages to maintain in-

27 Available at: https://www.eurozine.com/growing-up-in-kunderas-central-europe/ (10 December 2019). 
terest towards cohesion. That was visible in the functioning of the Habsburg Monarchy, in the German orientation in the interwar period and the position of the Soviet Union after 1945. But what happens if a great power loses its strength? Well, according to Majoros, then comes the time for nostalgia, the discussion about orientation and Westernisation, as happened last time during Gorbachev's regime.

The biggest problem according to Majoros is based on the contradiction between expectation and reality. He quotes György Schöpflin, member of the European Parliament and the Hungarian-born-English political scientist, who stated that at the European integration in 2004, the Central European states joined an imagined Europe and the core of the disappointment, the negative experience, the frustration, is all based on this contradiction.

\section{Conclusion}

The idea of Central Europe assumes some common approach to the past; common cultural values and experience that is in contradiction with the problems of its multi-ethnic structure. Although the turn of the 1980s and 1990s was overwhelmed with nostalgia which was reinforced by the support of trans-Atlantic orientation and the core of the Central European region justified their Western orientation with NATO and the European Union's membership, after the first years of euphoria, more detailed, even critical arguments were composed in connection with the rationality of the Central Europe concept.

"The U.S. State Department decided that Eastern Europe no longer exists. Its embassies worldwide are being instructed »that the words Eastern Europe will be banished from the lexicon « of the agency, Assistant Secretary of State Richard Holbrooke told Congress. He said the region will be referred to as Central Europe, as it was before 1939. Despite Europe's politically directional designations after World War II, he said, »the people of the region themselves do not consider themselves Eastern Europeans «."28

Looking back over the centuries, Central and Eastern Europe was always a playground for the great powers and the survival of these states was strongly influenced by their ability to cooperate. The euphoria of sovereignty and independence has sometimes hampered and continues to obstruct acceptance of the EU's operating institutional framework; instead of conforming, these states have shown a tendency to propose new norms that may inevitably shock older member states and their diplomats. (Schmidt 2016) As there was a general preconception that there existed the East, the West and a region between East and West which politically showed more common elements with the East

28 Romiscs, Available at: http://epa.oszk.hu/00400/00458/00549/pdf/EPA00458_korunk_2016_07_074-089. pdf (10 December 2019). 
but which was part of the Western culture, nowadays, after Euro-Atlantic integration, demonstrates just the opposite. Politically, they are still members of the European Union, however, they are demonstrating many more common values with the East. Speaking about the actual problems of the East-West division nowadays, the Central European issue appears as a crucial problem in the European Union. As Pacella remarks, the most questionable issue is not about heritage or identity but the problems of democracy. ${ }^{29}$

Whereas western Europe witnessed a liberal model of multi-ethnic societies being established over nearly half a century, with some variants, eastern Europe experienced closed societies prior to 1989 and has not experienced migrations from the South since, at least not up until now. These nations had been colonised and did not share the West's postcolonial complex. And, most importantly, there is a very widespread perception in the east of Europe that the western multicultural model is now an abhorrent failure.

\section{References}

Ash, T.G.: The Puzzle of Central Europe http://www.visegradgroup.eu/the-visegrad-book/ash-timothy-garton-the.

Appelbaum, Anne (2016): Kelet és Nyugat között - Európa határvidékén, Örökség Kultúrpolitikai Intézet, Budapest.

Berend, Nora (2013): Central Europe in the High Middle Ages: Bohemia, Hungary and Poland, c. 900-c.1300, Cambridge University Press.

Bialasiewicz, Luiza (2003): Another Europe: Remembering Habsburg Galicia. Cultural Geographies 10: 21-44.

Bialasiewicz, Luiza (2009): Europe as/at the border: Trieste and the meaning of Europe. Social and Cultural Geography 10(3): 319-333.

Bibó István: (1986) A kelet-európai kisállamok nyomorúsága. In: Bibó István: Válogatott tanulmányok, 2. Magvető Kiadó, Budapest.

Bibó, István: (1986) Az európai egyensúlyról es a békéről. In: Bibó, István: Válogatott tanulmanyok, 1. Magvető Kiadó, Budapest.

Csaky, Moritz: Elfelejtsük-e? Available at: http://ketezer.hu/2015/05/kozep-europa-felejtsuk-el-4/ (10 December 2019).

Denni, Karen (2009): Central Europe as a Transition Zone between East and West. Traditiones, 38/2: 59-71.

29 This time, it is nothing to do with heritages, history or common culture. It is only about how the states of Central Europe face current problems and issues... If, before, the cause of increasing Europe's East-West divide was a need to achieve Western democracy, today, it is a lack of democratic values which divides the West from the East.

Available at: http://www.fomoso.org/en/opinions/commentaries/the-new-tragedy-of-central-europe/ (10 December 2019). 
Glied, Viktor - Pap, Norbert (2016): The Christian Fortress of Hungary - The Anatomy of the Migration Crisis in Hungary. In: Yearbook of Polish European Studies, Vol. 19/2016.

Hamerli, Petra (2018): A Magyar - olasz kapcsolatok regionális hatásai 1927 és 1936 között. In: Közép - Európai Közlemények, XI. 2018/4: 9-34.

Hanák, Péter (2018): Közép-Európa keresi önmagát, 1988. In: LIGET Műhely, 2018 Available at: https://opinionator.blogs.nytimes.com/2012/01/09/where-is-europe/(10 December 2019).

Havel, Vaclav: Allocution prononcée devant la Diéte et le Sénat polonais. Varsovie, le 25 janvier 1990. In: L'angoisse de la Liberté. Paris, Éditions del'aube, pp. 68-78. In: Denni, Karen (2009): Central Europe Central Europe as a Transition Zone between East and West, Traditiones 38/2: 59-71.

Horváth, Sándor: Kell nekünk KözépEurópa (is). Available at: http://ketezer.hu/2015/02/kozep-europa-felejtsuk-el-3/ (10 December 2019).

Kaczorowski, Aleksander: Farewell to Central Europe. Available at: https://www.aspenreview. com/article/2017/farewell-to-central-europe/ (10 December 2019).

Kepplová, Zuzana: Could the Real Tragedy of Central Europe Please, Stand up? Available at: https://visegradinsight.eu/recycled-rhetoric/ (10 December 2019).

Közép Európa. Felejtsük el? 2000 folyóirat, 2014/12 Available at: http://ketezer.hu/2015/05/ kozep-europa-felejtsuk-el-5/(10 December 2019).

Lengyel, László (2016): Halott ország, Helikon, Budapest

Maci, Daniela (2011): East European Identity versus West European Identity. Annales Philosophici 3/ 2011: 30-36.

Majoros, István (2009): Közép- Európa nyomában... viták, vélemények a régióról. Available at: http://acta.bibl.u-szeged.hu/29697/1/kek_003_055-060.pdf (10 December 2019).

Kundera: The Tragedy of Central Europe. Available at: http://www.kx.hu/kepek/ises/anyagok/ Kundera_tragedy_of_Central_Europe.pdf (10 December 2019).

Miletics Péter - Pál Viktor (1998): A közép-európai tér fejlődésének kérdései. Földrajzi Értesítő 1998/2: 217-233.

Romsics, Ignác (2016): Közép- és/vagy Kelet-Európa - egy definiciós vita és ami mögötte van, In: Korunk História, 2016/7.

Schmidt, Andrea (2016): Friends forever? The Role of the Visegrad Group and European Integration, Politics in Central Europe 12: (3): 113-140.

Schmidt, Andrea (2010): The Eastern Borders of Europe - Symbolic, Historical and Cultural Aspects, In: Borderless Europe. Challenges, Opportunities, Publikon, Pecs.

Scruton (2005): A nemzetek szükségességéről, Helikon.

Snyder, Timothy (2019): A szabadság felszámolása, 21. Század Kiadó, Budapest.

Sorin, Antohi (1996): A románok 1995-ben: szimbolikus földrajz és társadalmi identitás In: Magyar Kisebbség, 1996-4 sz.

Szűcs Jenő (1981): Vázlat Európa három történeti régiójáról. Történelmi Szemle, 1981-3. 
Trencsényi Balázs et al. (2016): A History of Modern Political Thought in East Central Europe Volume I: Negotiating Modernity in the 'Long Nineteenth Century', Oxford University Press. von Lowis, Sabine (2015): Phantom Borders in the Political Geography of East Central Europe: An Introduction. Erdkunde 69(2): 99-105.

Andrea Schmidt, PhD is a political scientist and an Associate Professor at the University of Pecs, Hungary, Department of Political Sciences, and International Studies and former Visiting Lecturer and the Josai Institute for Central European Studies Josai International University, Tokyo, Japan, and Visiting Lecturer at Ivan Franko National University in L'viv, Ukraine. She studied at the University of Pecs, the Eötvös Lóránd University in Budapest and at the Central European University where she participated at Modern History programme focusing on Central and Eastern Europe. She also studied at the Jagiellonian University at the Faculty of History and at the Polonia Research Institute in Cracow, Poland. She specializes in International Political Economy and Comparative Political Studies of the Central and Eastern European region. She did her habilitation on International Relations focusing on Geo-economics. She is the author of several articles and book chapters related to Central and Eastern European and post-Soviet region. 